\title{
National Library Week: "Libraries Change Lives"
}

\author{
By Linda $\mathrm{K}$. Wallace
}

\section{Join the celebration of libraries' impact on people's lives}

$\mathbf{T}$ he theme for National Library Week (NLW) 1993, and 1994, is "Libraries Change Lives." This is the first time the NLW theme has been selected for two consecutive years. The dates are April 18-24, 1993, and April 17-23, 1994.

Nancy Davenport, 1991-92 chair of the National Library Week Committee, noted that the theme complements the "Books Change Lives" theme adopted by the Library of Congress for 1993 and 1994 and allows more planning time.

It also ties in with 1992-93 ALA president Marilyn Miller's theme "Empowering People through $\mathrm{Li}$ braries" and focuses attention on the contributions of libraries at a time when many are having to fight budget cuts, Davenport noted.

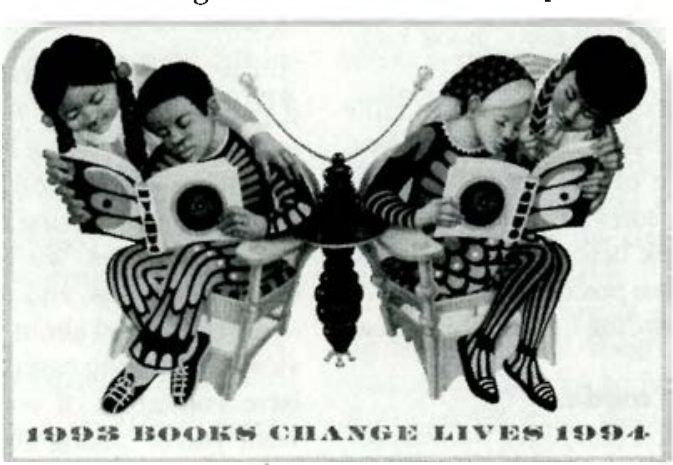

Award-winning illustrators Leo and Diane Dillon portray the transforming power of books in a commemorative poster for the Library of Congress' Books Change lives theme. (available from $A L A$ )

A national search for those whose lives have been changed by libraries and/or librarians will be sponsored by ALA. Those wishing to "testify" will be invited to send a postcard stating "How the library changed my life."

The testimony will be used to demonstrate to legislators at the local, state, and national levels the value that people place on libraries. All testimony must be verifiable and include full name, age, and address.

Those who would like to be considered for a national advertising campaign may submit statements of up to 75 words. These may be written in prose, poetry, rap, or other forms. Photos, drawings, and audio- or videotapes may also be submitted. All ages are invited to share their thoughts.

Libraries may collect testimony and honor their "Library lives" stars during NLW activities such as the Night of a Thousand Stars/Great

National Library Week posters, bookmarks, pins, and other promotional materials can be ordered from the fall ALA Graphics Catalog as can "Books Change Lives" posters and promotional items.

The 1993-94 Library Campaign Book, also available from ALA Graphics, will include library program and promotion ideas and clip art for promoting both the "Books Change Lives" and "Libraries Change Lives" themes.
American Read Aloud scheduled for Wednesday, April 21. Original entries must be forwarded to ALA headquarters by May 1 .

Three people whose lives have been changed by libraries will be selected for honoring at the Opening General Session of the 1993 ALA Annual Conference in New Orleans.

For more information contact: ALA Public Information Office, $50 \mathrm{E}$. Huron St., Chicago, IL 60611 ; (800) 545-2433, ext. 5044 or 5041. 


\section{Ideas for celebrating NLW}

- Invite the college president to issue a "National Library Week" proclamation acknowledging the library's contributions.

- Recruit a journalism class to interview students, faculty, administrators, and visiting VIPs on "How Books and the Library Changed My Life." Have photography students take shots to accompany the interviews. Publish all this in a special National Library Week newsletter or in the library's (maybe even the college's) annual report.

- Do a "Changing Lives . . . Changing Libraries" exhibit. Pick a significant year in the life of the school and contrast library and information resources then and now using posters and other memorabilia. Include photos and lists such as "Bestsellers then-and now," "The card catalog then-and now," "The librarian then-and now," and "The library collection then-and now." Suggest this as a feature story to campus and community newspapers.

- Start a running notebook near the circulation desk asking those in line to jot down their thoughts on how the library changed their lives. Select a "quote of the week" for posting.

- Hold a National Library Week daily drawing. Have entrants write their thoughts on "How Books and the Library Changed My Life" on a postcard. Draw daily winners and be generous in awarding T-shirts, buttons, and gift certificates as prizes. Send copies of entries to the ALA Public Information Office as part of the national "Libraries Lives" search.

- Send a letter to distinguished faculty and alumni inviting them to share their thoughts. Create a special bulletin board display. Submit an article to the alumni magazine.

- Have student copywriters write "commercials" about the life-changing impact of the college library-or books and libraries in general. Ask a local advertising or public relations association to select "winners" and recruit a local TV station or the Broadcast Communications Department to produce them. Submit them as public service advertising for campus and community stations. Suggest a story about the cooperative venture for the station-or local newspaper.

\title{
Declining Aquisition Budgets: Allocation, Collection Development, and Communication of Impact Oklaboma City, Oklaboma February 25-26, 1993
}

\author{
Speakers:
}

Ross Atkinson - Cornell University

Kathleen Born - EBSCO

Gay Dannelly - Ohio State University

Nancy Eaton - Iowa State University

Anthony Ferguson - Columbia University

Charles Hamaker - Louisiana State University

Leonard Schrift - Ballen Booksellers

Judy Webster - University of Tennessee-Knoxville

Contact for Information: Donald C. Hudson, University of Oklahoma Libraries, Norman, OK 73019-0528 Phone: 405-325-2611 


\section{On Microfilm:}

L'Express Le Figaro Le Point

Corriere della Sera O La Stampa

Al-Ahram The Jerusalem Post

Asahi Shimbun Japan Times China Daily

Der Spiegel O Stern Die Welt $\bigcirc$ Die Zeit

Lidové Noviny (Prague)

Prague Post Baltic Observer

The Forward (N.Y.)

And many more...

At the Foreign List Price

Invoiced in Dollars from New York

Norman Ross Publishing Inc.

330 West 58th Street, New York, NY 10019 212-765-8200 O 800-648-8850 O FAX 212-765-2393 